\title{
Exordio a "Una Celebración de los Aniversarios Darwinianos de 2009"
}

\section{Exordium to "A Celebration of the Darwinian Anniversaries of 2009"}

\author{
Guillermo D’Elía \\ Departamento de Zoología \\ Universidad de Concepción, Concepción, Chile \\ E-mail: guillermo@udec.cl
}

Icono pop, revolucionario, el más grande naturalista de todos los tiempos, una de las personas más influyentes de la humanidad, son algunos de los calificativos que afloran cuando pensamos en Charles Robert Darwin (Darwin). A lo largo de 2009 hemos visto cómo el mundo celebra dos aniversarios darwinianos: dos siglos del nacimiento de Darwin (12 de febrero de $1809^{1}$ ) y 150 años de la publicación (24 de noviembre de 1859) de la que es la obra científica -El Origen de las Especies² - más importante de todas aquéllas escritas. Esta última es la razón, claro, por la cual celebramos también la primera (así como la amplia mayoría desconoce el nombre de cualquier otra de las miles y miles de personas que nacieron en $1809^{3}$; muchos también desconocen el nombre de alguna de las otras obras escritas por Darwin $\left.{ }^{4}\right)$.

${ }^{1}$ Es de interés recordar que 1809 fue también el año de publicación de Philosophie zoologique ou exposition des considérations relatives à l'histoire naturelle des animaux por Jean-Baptiste Lamarck.

${ }^{2}$ Por tradición de uso empleare "El Origen" (y no "Acerca del Origen") para referirme en forma breve a On the origin of species by means of natural selection, or the preservation of favoured races in the struggle for life.

${ }^{3}$ Como nota Niles Eldregde (2005: 7), curiosamente el 12 de febrero de 1809 también nació Abraham Lincoln; ambos personajes son ahora homenajeados en sendos billetes de sus respectivos países. Darwin aparece desde 2000 en los billetes de 10 libras. Llamativamente, en dicho billete, además de Darwin, junto a unas flores amarillas, una lupa y un diminuto Beagle, un picaflor ocupa un lugar preponderante; si de aves se trataba, es claro que hubiese sido bastante más oportuno incluir un pinzón de las Galápagos o un ñandú.

${ }^{4}$ Para aquellos interesados, el sitio The Complete Work of Charles Darwin Online (http://darwin-online.org.uk/) constituye un recurso invalorable al momento de acceder a la producción escrita de Darwin, ya sean libros, artículos, manuscritos, cartas y todo tipo de documentos personales; también contiene una extensa serie de trabajos sobre Darwin y relacionados a su obra. Algunos de los textos que se mencionan en este Exordio fueron leídos en dicho portal.
El Origen de las Especies no sólo redefine las ciencias naturales; redefine también nuestro lugar en la naturaleza, a la vez que desecha la necesidad de invocar cualquier fuerza sobrenatural para explicar procesos orgánicos. Las nuevas propuestas de Darwin dieron vuelta la mesa. Darwin desplazó, más allá de algunos resurgimientos místicos (como el de Teilhard de Chardin, 1955), al esencialismo, al vitalismo y al determinismo, a la vez que instauró el pensamiento poblacional y la concepción de la selección natural, así como evidenció la importancia de la contingencia y puso de manifiesto la relevancia explicativa del factor tiempo (Mayr, 2004).

En el último párrafo del capítulo VI de El Origen, alejándose del foco de ese capítulo (Difficulties on Theory), Darwin plantea de forma contundente e innovadora la explicación para dos observaciones centrales en historia natural.

It is generally acknowledged that all organic beings have been formed on two great laws-Unity of Type, and the Conditions of Existence. By unity of type is meant that fundamental agreement in structure, which we see in organic beings of the same class, and which is quite independent of their habits of life. On my theory, unity of type is explained by unity of descent. The expression of conditions of existence, so often insisted on by the illustrious Cuvier, is fully embraced by the principle of natural selection. For natural selection acts by either now adapting the varying parts of each being to its organic and inorganic conditions of

Pp. 1-6 en D’Elía, G. 2009. Una celebración de los aniversarios darwinianos de 2009. Gayana 73 (suplemento): 1-88. 
life; or by having adapted them during long-past periods of time: the adaptations being aided in some cases by use and disuse, being slightly affected by the direct action of the external conditions of life, and being in all cases subjected to the several laws of growth. Hence, in fact, the law of the Conditions of Existence is the higher law; as it includes, through the inheritance of former adaptations, that of Unity of Type.

Darwin (1859: 206)

En términos actuales diríamos que la similitud entre organismos se debe a la herencia de estados de carácter desde su ancestro común y en ciertos casos a la acción de la selección natural frente a presiones selectivas similares, dada, por supuesto, la existencia de la variación necesaria. Debido a su gran poder explicativo, la propuesta de descendencia común fue aceptada por la mayoría de los biólogos poco después de la publicación de El Origen. Por ejemplo, los arquetipos que los anatomistas como Owen habían vislumbrado pasaron a ser entendidos como el resultado de la herencia de estados de carácter desde un ancestro común a sus descendientes. Así, la jerarquía Linneana pasó a tener una sólida explicación biológica. Luego de un devenir más complejo, la selección natural es hoy ampliamente aceptada, habiéndose descartado las teorías finalistas y neo-lamarckianas. También es cierto que actualmente se asigna al azar un papel más importante que el visualizado por Darwin y posteriormente por los neo-darwinistas.

De la idea de descendencia con modificación (que lleva implícita la noción de transmutación o evolución) es que se desprende que nuestra especie es una más de las tantas que han florecido en el árbol de la vida; en ese sentido, no tenemos nada especial. Por otro lado, tenemos un mecanismo biológico, la selección natural, que es impersonal y descriptible, y que nos ahorra el tener que subyugarnos a la voluntad, intervención y supervisión de cualquier poder sobrenatural. Es más, no hay un fin ni hay meta; lo único cierto es que habrá más cambio. Dicho esto, es sencillo entender por qué hablamos de revolución darwiniana ${ }^{5}$ y por qué, a lo largo

\footnotetext{
${ }^{5}$ En un famoso ensayo de 1917 (Eine Schwierigkeit der Psychoanalyse / Una dificultad del psicoanálisis) Sigmund Freud enumeró los tres golpes mayores al narcisismo humano. Previsiblemente, el segundo en
}

de estos 150 años, ciertos sectores reaccionarios se han opuesto al darwinismo y a la teoría de la evolución.

Hoy, 150 años después de la publicación de El Origen, la expansión de las ideas evolutivas en general, y de la selección natural en particular, ha alcanzado a aquellas disciplinas, como la antropología, con una clara base en la historia natural. Es así que existe una rama evolutiva (o evolucionaria según el decir chileno) de la medicina (e.g., Williams \& Nesse, 1991) y de la psicología ${ }^{6}$ que tratan de comprender en un contexto evolutivo nuestra salud, comportamiento y emociones (incluyendo por ejemplo nuestras decisiones sobre intercambios comerciales; e.g., Shermer, 2009). Al mismo tiempo, la incorporación de ideas darwinianas en disciplinas más alejadas, como la cosmología, continúa, aunque con variado éxito (ver revisión de Derry, 2009).

\section{EL PRESENTE NÚMERO Y SU RAZÓN}

Es intención de Gayana ser parte de las celebraciones darwinianas de 2009; con tal fin se edita este número especial de ensayos relacionados a la teoría evolutiva y al darwinismo. Son varios los motivos que vuelven natural este volumen de Gayana. Lo expresado en la sección anterior constituye motivo suficiente, pero también existen otras razones que justifican que una revista editada en Chile y cuyo nombre es Gayana, forme parte activa de las conmemoraciones.

Independientemente de las dudas existentes respecto al momento (i.e., antes, durante o después del viaje del Beagle) y forma en que Darwin comenzó a sospechar que las especies no eran inmutables (ver Sulloway, 1982), es claro que dicha transformación intelectual esta íntimamente ligada a su viaje en el Beagle y en particular a su paso por el sur de

\footnotetext{
esta lista es el propiciado por Darwin al mostrar que el hombre es parte de un continuo que incluye a los demás animales. El primero indica Freud se sintió cuando Copérnico estableció que la Tierra no era el centro del Universo. Finalmente, el tercer golpe habría sido dado por él mismo al mostrar que el hombre no tiene control sobre los aspectos más importantes de sus procesos mentales.

${ }^{6}$ Mostrando una vez más la claridad que poseía sobre el alcance y grado de innovación de su obra, cerca del final de El Origen, en la página 488, Darwin escribe: "In the distant future I see open fields for far more important researches. Psychology will be based on a new foundation, that of the necessary acquirement of each mental power and capacity by gradation. Light will be thrown on the origin of man and his history".
} 
Exordio.

América del Sur ${ }^{7}$. No en vano El Origen comienza de la siguiente forma:

\begin{abstract}
When on board H.M.S. 'Beagle, 'as naturalist, I was much struck with certain facts in the distribution of the inhabitants of South America, and in the geological relations of the present to the past inhabitants of that continent. These facts seemed to me to throw some light on the origin of species-that mystery of mysteries, as it has been called by one of our greatest philosophers.
\end{abstract}

(Darwin, 1859: $1^{8}$ )

Durante su visita a Chile Darwin conoció personalmente a Claudio Gay, el naturalista francés que es homenajeado en el nombre de esta revista. Dado que Darwin no hablaba francés ni Gay inglés se comunicaron en español. En dicho encuentro, Gay le entregó a Darwin una copia de su informe de 1833 sobre geología sudamericana con énfasis en la chilena (Urzúa, 2009). Darwin cita repetidas veces dicho informe en su diario de viaje $(1839)^{9}$ donde también caracterizó a Gay como “... a zealous and able naturalist, is now occupied in studying every branch of natural history throughout the kingdom of Chile".

Este número especial de Gayana está compuesto por seis ensayos escritos por siete investigadores. Abren el volumen dos ensayos que giran, respectivamente,

\footnotetext{
${ }^{7}$ Una percepción minoritaria (e.g., Ruse, 2008), es que tanto o más determinante que el paso por las Islas Galápagos para que ese "clic" intelectual ocurriese, fue el impacto causado por sus experiencias con los habitantes del extremo sur de nuestro continente. De particular importancia habría sido su reencuentro en Tierra del Fuego con "Jemmy Button" el 5 de marzo de 1834 luego de poco más de un año sin verse. "Jemmy Button" era el apodo dado a uno de los tres fueguinos que regresaron a su tierra natal en el Beagle junto a Darwin, luego de haber pasado alrededor de tres años en Inglaterra, a donde habían sido llevados por Robert FitzRoy en una expedición anterior.

${ }^{8}$ En la tercera edición de El Origen publicada en 1861, Darwin modificó dos partes de este párrafo. Es así que a partir de entonces el mismo se lee (modificaciones subrayadas por mí): "When on board H.M.S. 'Beagle, as naturalist, I was much struck with certain facts in the distribution of the organic beings inhabiting South America, and in the geological relations of the present to the past inhabitants of that continent. These facts, as will be seen in the latter chapters of this volume, seemed to throw some light on the origin of species- that mystery of mysteries, as it has been called by one of our greatest philosophers". Probablemente estas modificaciones hayan sido propiciadas, al menos en parte, por la virulenta crítica realizada a la versión original de El Origen de forma anónima por Richard Owen (1860).

${ }^{9}$ Incluyendo una oportunidad donde manifiesta (1839: 290) cierto desacuerdo con Gay sobre la naturaleza de un tipo particular de roca.
}

en torno al asentamiento del darwinismo y a la enseñanza de la biología evolutiva en Chile; los dos siguientes tienen como protagonistas a Darwin y Alfred Russel Wallace, los codescubridores de la selección natural; el quinto ensayo se centra en la domesticación animal y selección artificial, que ocupan un papel central en la argumentación de Darwin -no en vano el primer capítulo de El Origen lleva por nombre "Variation Under Domestication"; el número se cierra con un ensayo que repasa los acontecimientos fundamentales de la teoría evolutiva en el último siglo.

En el primer ensayo, Rodrigo Medel \& Alberto Veloso (2009) recorren el Chile social y cultural visitado por Darwin, para luego elaborar sobre el impacto de las ideas darwinistas en Chile. Los autores identifican tres etapas en el proceso que desemboca en el presente donde la biología evolutiva continúa su expansión y consolidación en el país. Patricio Camus (2009), en el segundo ensayo, se centra en un aspecto fundamental para que la actual etapa de expansión y consolidación de la biología evolutiva en Chile pueda continuar. Éste refiere a la educación secundaria y terciaria en biología y evolución. Entre otros aspectos, Camus enfatiza la importancia de una mejor y más efectiva articulación entre biólogos y pedagogos como forma de potenciar la alfabetización biológica en Chile.

Alfred Rusell Wallace es visto por algunos, incluyendo parte de sus biógrafos, como una víctima del "stablishment" científico de su época que le arrebató su cuota de crédito como descubridor del mecanismo de la selección natural. En relación a lo anterior, es necesario recordar que Wallace usaba la palabra darwinismo como sinónimo de teoría de selección natural; de hecho tituló Darwinism: An Exposition of the Theory of Natural Selection with Some of Its Applications un libro que publicó en 1889, siendo así responsable en buena medida de la acepción que desde entonces se le da a la palabra darwinismo. También es más que claro que Wallace no fue una suerte de Pierre Menard ${ }^{10}$ que escribió "de nuevo" la selección natural; Wallace y Darwin descubrieron en forma paralela la selección natural

${ }^{10}$ Pierre Menard, autor del Quijote es un cuento escrito por Jorge Luis Borges y que aparece en su libro El Jardín de Senderos que se Bifurcan (1941). 
y así son recordados ${ }^{11}$.

${ }^{11}$ On the Tendency of Species to form Varieties; and the Perpetuation of
Varieties and Species by Natural Means of Selection es el nombre genérico
con el que el 1 de julio de 1858 se leyeron por parte de Charles Lyell y
Joseph Hooker y luego publicaron (Journal of the Proceedings of the
Linnean Society of London. Zoology 3 (20 Aug.): 46-50) los ensayos de
Darwin y Wallace donde dan a conocer el mecanismo de selección natural.
A continuación transcribo la introducción realizada por Lyell y Hooker a
dichos ensayos.

London, June 30th, 1858.

My Dear Sir-The accompanying papers, which we have the honour of communicating to the Linnean Society, and which all relate to the same subject, viz. the Laws which affect the Production of Varieties, Races, and Species, contain the results of the investigations of two indefatigable naturalists, Mr. Charles Darwin and Mr. Alfred Wallace.

These gentlemen having, independently and unknown to one another, conceived the same very ingenious theory to account for the appearance and perpetuation of varieties and of specific forms on our planet, may both fairly claim the merit of being original thinkers in this important line of inquiry; but neither of them having published his views, though Mr. Darwin has for many years past been repeatedly urged by us to do so, and both authors having now unreservedly placed their papers in our hands, we think it would best promote the interests of science that a selection from them should be laid before the Linnean Society.

Taken in the order of their dates, they consist of:-

1. Extracts from a MS. work on Species*, by Mr. Darwin, which was sketched in 1839, and copied in 1844, when the copy was read by Dr. Hooker, and its contents afterwards communicated to Sir Charles Lyell. The first Part is devoted to "The Variation of Organic Beings under Domestication and in their Natural State;" and the second chapter of that Part, from which we propose to read to the Society the extracts referred to, is headed, "On the Variation of Organic Beings in a state of Nature; on the Natural Means of Selection; on the Comparison of Domestic Races and true Species."

2. An abstract of a private letter addressed to Professor Asa Gray, of Boston, U.S., in October 1857, by Mr. Darwin, in which he repeats his views, and which shows that these remained unaltered from 1839 to 1857.

3. An Essay by Mr. Wallace, entitled "On the Tendency of Varieties to depart indefinitely from the Original Type." This was written at Ternate in February 1858, for the perusal of his friend and correspondent Mr. Darwin, and sent to him with the expressed wish that it should be forwarded to Sir Charles Lyell, if Mr. Darwin thought it sufficiently novel and interesting. So highly did Mr. Darwin appreciate the value of the views therein set forth, that he proposed, in a letter to Sir Charles Lyell, to obtain Mr. Wallace's consent to allow the Essay to be published as soon as possible. Of this step we highly approved, provided Mr. Darwin did not withhold from the public, as he was strongly inclined to do (in favour of Mr. Wallace), the memoir which he had himself written on the same subject, and which, as before stated, one of us had perused in 1844, and the contents of which we had both of us been privy to for many years. On representing this to Mr. Darwin, he gave us permission to make what use we thought proper of his memoir, \&c.; and in adopting our present course, of presenting it to the Linnean Society, we have explained to him that we are not solely considering the relative claims to priority of himself and his friend, but the interests of science generally; for we feel it to be desirable that views founded on a wide deduction from facts, and matured by years of reflection, should constitute at once a goal from which others may start, and that, while the scientific world is waiting for the appearance of Mr. Darwin's complete work, some of the leading results of his labours, as well as those of his able correspondent, should together be laid before the public.

We have the honour to be yours very obediently,

Charles Lyell.

Jos. D. Hooker.

* This MS. work was never intended for publication, and therefore was not written with care.-C. D. 1858.
Sin embargo, no deja de ser llamativo el hecho de que Wallace, uno de los codescubridores de la Selección Natural, abandonase este mecanismo cuando se trata de explicar la evolución de la mente humana. En un iluminador ensayo Steven Glickman (2009) plantea cuáles podrían haber sido las causas de dicha deserción, destacando el papel que podrían haber jugado ciertas particularidades de Wallace. No menos enriquecedor es entender que la posición de Wallace en torno a la evolución de la mente humana propició la escritura por parte de Darwin de dos obras claves The Descent of Man and Selection in Relation to Sex de 1871 y Expression of the Emotions in Man and Animals de 1873.

Hoy por hoy es en buena medida un cliché afirmar que El Origen no trata sobre cómo se originan nuevas especies y sí de la transformación de una misma línea filética. En el cuarto ensayo, James Mallet (2009) elaborando sobre un trabajo de 1865 de Wallace sobre mariposas del archipiélago Malayo, nos ilustra cómo Darwin y sus contemporáneos, en particular Wallace, tenían un entendimiento cercano al actual sobre la naturaleza de las especies, y ciertamente mucho más acabado de lo que tradicionalmente se reconoce.

En un capítulo autobiográfico que apareció originalmente en el primero de tres volúmenes con cartas y otros documentos inéditos compilados por su hijo Francis Darwin (1887), Darwin recuerda la importancia que jugó en el desarrollo de su teoría ${ }^{12}$ el estudio de la variación en plantas y animales domésticos.

\section{After my return to England it appeared to me that ...... by collecting all facts which bore in any way on the variation of animals and plants under domestication and nature, some light might perhaps be thrown on the whole subject. My first note-book was opened in July 1837. I worked on true Baconian}

\footnotetext{
${ }^{12}$ Según Ernst Mayr (2004), la teoría darwiniana son en realidad cinco teorías evolutivas independientes una de otra desde un punto de vista lógico. Estas son: 1) la evolución como tal o la teoría de la inconstancia de las especies; 2) la teoría de la descendencia común, por la cual se establece que todos los organismos descienden de un ancestro común; 3) la que establece que el cambio es gradual y no da saltos; 4) una explicación sobre como se multiplican las especies (i.e., la especiación y no sólo la transformación filética); y 5) la teoría de la selección natural como mecanismo de cambio.
} 
principles, and without any theory collected facts on a wholesale scale, more especially with respect to domesticated productions by printed enquiries, by conversation with skilful breeders and gardeners, and by extensive reading. ...... I soon perceived that selection was the keystone of man's success in making useful races of animals and plants. But how selection could be applied to organisms living in a state of nature remained for some time a mystery to me. ${ }^{13}$

(Darwin en F. Darwin, 1887: 83)

Es así que, en el quinto ensayo, Claudio Bidau (2009) pasa revista a las ideas sobre domesticación y las visiones que se tienen sobre el uso que hizo Darwin para luego presentarnos un espectacular experimento sobre domesticación en zorros diseñado por el genetista Dmitry $\mathrm{K}$. Belyaev, y que comenzó justo 100 años después de la publicación de El Origen. El ensayo se cierra con un repaso de las luces que el experimento, aún en marcha, ha arrojado sobre la teoría de la domesticación.

En el último ensayo Enrique Lessa (2009) presenta una revisión histórica del significado y legado del darwinismo, con énfasis en el último siglo. Su tesis es que con los ajustes derivados del conocimiento generado en dicho periodo, el darwinismo sigue vigente en nuestros días.

Queda así explicada la naturaleza de este número especial de Gayana que pretende constituir un modesto homenaje a Charles Darwin y su obra.

\section{AGRADECIMIENTOS}

Quiero expresar mi gratitud a Andrés Angulo, director de Gayana, por haber apoyado de forma entusiasta mi propuesta de llevar adelante este número especial. Vaya también mi reconocimiento a la ayuda prestada por Cristina Sierra en relación a distintos aspectos de la edición de este número. Por último, mi mayor agradecimiento a los autores de los ensayos quienes con su valioso aporte hicieron posible este homenaje.

${ }^{13}$ Darwin luego agrega que el haber leído en octubre de 1838 el ensayo de Robert Thomas Malthus An Essay on the Principle of Population (1798) le dio el indicio necesario para visualizar el mecanismo de la selección natural.

\section{BIBLIOGRAFÍA}

BIDAU, C.J. 2009. Domestication through the centuries: Darwin's ideas and Dmitry Belyaev's long-term experiment in silver foxes. En: Una celebración de los aniversarios darwinianos de 2009 (Ed. D'Elía, G), pp. 55-72. Gayana 73 (suplemento): 1-88.

CAmus, P.A. 2009. Educación científica y evolutiva en Chile: problemas funcionales y conflictos entre enseñar y aprender. En: Una celebración de los aniversarios darwinianos de 2009 (Ed. D’Elía, G), pp. 19-31. Gayana 73 (suplemento): 1-88.

Darwin, C. R. 1839. Narrative of the Surveying Voyages of His Majesty's Ships Adventure and Beagle Between the Years 1826 and 1836, Describing their Examination of the Southern Shores of South America, and the Beagle's Circumnavigation of the Globe. Journal and remarks. 1832-1836. Henry Colburn, London.

Darwin, C.R. 1859. On the Origin of Species by Means of Natural Selection, or the Preservation of Favoured Races in the Struggle for Life. John Murray, London.

DARWIN, F. 1887. The Life and Letters of Charles Darwin, Including an Autobiographical Chapter. Volume 1. John Murray, London.

Derry, J.F. 2009. Darwin in disguise. Trends in Ecology and Evolution 24(2):73-79.

Eldredge, N. 2005. Darwin, Discovering the Tree of Life. W.W. Norton, New York.

GAY, C. 1833. Aperçu sur les recherches d'histoire naturelle faites dans l'Amérique du Sud, et principalement dans le Chili, pendant les années 1830 et 1831 . Annales des Sciences Naturelles 28: 369-93.

Glickman, S.E. 2009. Charles Darwin, Alfred Russel Wallace, and the evolution / creation of the human brain and mind. En: Una celebración de los aniversarios darwinianos de 2009 (Ed. D’Elía, G), pp. 32-41. Gayana 73 (suplemento): 1-88.

Lessa, E.P. 2009. Vigencia del darwinismo. En: Una celebración de los aniversarios darwinianos de 2009 (Ed. D’Elía, G), pp. 73-84. Gayana 73 (suplemento): 1-88.

MalLet, J. 2009. Alfred Russel Wallace and the Darwinian species concept: his paper on the swallowtail butterflies (Papilionidae) of 1865. En: Una celebración de los aniversarios darwinianos de 2009 (Ed. D’Elía, G), pp. 42-54. Gayana 73 (suplemento): 1-88.

MAYR, E. 2004. What Makes Biology Unique? Considerations on the Autonomy of a Scientific Discipline. Cambridge University Press, New York.

Medel, R. \& A. Veloso. 2009. Establecimiento y propagación del darwinismo en Chile: Recepción y elaboración de las ideas. En: Una celebración de los aniversarios darwinianos de 2009 (Ed. D'Elía, G), pp. 7-18. Gayana 73 (suplemento): 1-88.

OwEN, R. 1860 (1979). [Darwin on the Origen of Species]. Edinburgh Review CXI: 487-532. En: Darwin, a Norton Critical Edition. Second Edition (Ed. 
Appleman, P.), pp. 223-226. W. W. Norton \& Company, New York.

Ruse, M. 2008. Charles Darwin. Katz Editores, Madrid. SHermer, M. 2009. The Mind of the Market: How Biology and Psychology Shape Our Economic Lives. Holt Paperbacks, New York.

Sulloway, F. 1982. Darwin's conversion: the Beagle voyage and its aftermath. Journal of the History of Biology, 15(3):325-96.
Teilhard de Chardin, P. 1955 (1979). The Phenomenon of Man. En: Darwin, a Norton Critical Edition. Second Edition (Ed. Appleman, P.), pp. 334-342. W. W. Norton \& Company, New York.

Urzúa, C. 2009. Chile en los Ojos de Darwin. Ediciones B, Santiago de Chile.

Williams, G.C. \& R.M. Nesse. 1991. The dawn of Darwinian medicine. The Quarterly Review of Biology 66(1):1-22. 